Pamiętnik Literacki 2021, 2, s. 289-299

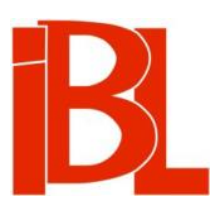

\title{
Badacz w archiwum i archiwum badacza. Paradoks archiwalny
}

\author{
Elżbieta Wichrowska
}


Pamiętnik Literacki CXII, 2021, z. 2, PL ISSN 0031-0514

DOI: $10.18318 / \mathrm{pl} .2021 .2 .20$

ELŻBIETA WICHROWSKA Uniwersytet Warszawski

\section{BADACZ W ARCHIWUM I ARCHIWUM BADACZA PARADOKS ARCHIWALNY}

Podstawowa praca historyka zarówno w, jak i z archiwum rozumianym tradycyjnie, jako miejsce gromadzenia zbiorów, polega na kontakcie ze źródłami będącymi tekstowymi i materialnymi świadectwami pewnych zjawisk i procesów literackich, kulturowych, społecznych czy politycznych. Archiwum dla historyka, niezależnie od mód metodologicznych, zawsze wiązać się powinno $\mathrm{z}$ realną przestrzenią gromadzenia zespołów akt i $z$ wiedzą na temat ich politycznych, społecznych uwarunkowań. To praca $z$ konkretnym, i to bez pośrednictwa innych mediów, przekazem, który można zbadać również pod względem materialnym.

Zwrot archiwalny nie tylko skierował oczy wielu specjalistów na archiwum i umieścił je w centrum ich refleksji (metodologicznej, historycznej, społecznej, politycznej itd.), ale znacznie rozszerzył definicję i zmetaforyzował pojęcie archiwum, dając początek rozumieniu, które wychodzi poza ramy wąskiego sensu - jako miejsca zabezpieczania, przechowywania i archiwizowania (też opracowywania) zbiorów ${ }^{1}$. Od tego czasu owa kategoria pełni funkcję wygodnej i atrakcyjnej pojęciowo metafory, wykorzystywanej w badaniach nad literatura, historia, sztuką lub filozofią, także - czy: zwłaszcza - tych dotyczących teraźniejszości i jej diagnozowania. Archiwum jest łączone albo wręcz staje się figurą dyskursu politycznego, metaforą instytucji władzy ${ }^{2}$ mającej realny wpływ na politykę, dystrybucji śladów wiedzy o przeszłości zapisanych w źródłach, które kształtują naszą pamięć. Archiwum okazuje się więc metaforą figury pamięci implikująca pytania właśnie o pamięć

1 Pojęcie zwrotu archiwalnego ma już obszerną literaturę przedmiotu. Historię zainteresowań problemem archiwum właśnie w tym kontekście przedstawiła syntetycznie $\mathrm{H}$. Markowska-F ula r a w artykule "Zwrot archiwalny” $w$ literaturoznawstwie polskim-teoria, praktyka, perspektywy (w zb.: Filozofia filologii. Red. A. Hellich, H. Markowska-Fulara, J. Potkański, Ł. Żu r e k. Warszawa 2019). Zob. też A. Leśnia k, Pozostałości archiwum. „Tytuł Roboczy: Archiwum" 2009, nr 3.

2 Chodzi o dyskurs dotyczący wiedzy i władzy, któremu patronuje nazwisko M. Foucaulta oraz jego Archeologia wiedzy (Przeł. A. Si e m e k. Wstęp J. To pols ki. Warszawa 1977).

3 Ważną rolę w takim potraktowaniu koncepcji archiwum (jako figury) odegrał J. D errida i jego wykład The Concept of the Archive: A Freudian Impression (Pojecie archiwum. Impresja freudowska) wygłoszony na konferencji Memory: The Question of Archive zorganizowanej przez Międzynarodowe Towarzystwo Historii Psychiatrii i Psychoanalizy w Londynie w 1994 roku. Angielska wersja wystapienia została opublikowana pod zmienionym tytułem: Archive Fever: A Freudian Impression (Gorączka archiwum. Impresja freudowska) w amerykańskim czasopiśmie „Diacritics” (1995, nr 2). 
z tezą o jej kryzysie: o polityki pamięci; o prawdę; o reguły konstruowania przeszłości i o próby wyjaśniania mechanizmów współczesnego świata; o zagrożenia; o to, co dziś dzieje się z „pamięcią” (czyli np. o procesy zapominania); o to, jaka pamięć jest nam potrzebna, a jaka jest możliwa; o sposoby jej reprodukowania (oraz niebezpieczeństwa $\mathrm{z}$ tym związane). Tak wyraźne i daleko idące zmetaforyzowanie pojęcia oraz funkcji archiwum, utożsamianie ich z pamięcią, spotyka się $z$ krytyką tej części badaczy ${ }^{4}$, dla której archiwum to przede wszystkim instytucja gromadząca zbiory, zatem winna być przedmiotem studiów dotyczących koncepcji i strategii segregowania, selekcjonowania, katalogowania w określonej polityczno-społecznej i kulturowej przestrzeni. Taka perspektywa otwiera inny typ pytan stawianych archiwum: o różne aspekty praktyk stosowanych w badaniach archiwalnych; o doświadczenie i poszukiwania archiwalne czy o rolę indywidualnego przeżycia archiwalnego; o znaczenie odkrycia archiwalnego i o to, co takim odkryciem jest, a co nie. Ale też: w jaki sposób druk i przekaz drukowany wpływają na widzenie zjawisk literatury, piśmiennictwa i kultury, na tworzenie kanonów? I pytanie o potrzebę badań archiwalnych - czyli o miejsce i rolę archiwum w pracy historyka literatury czy kultury lub edytora dzieł dawnych analizującego różne świadectwa tekstowe zwłaszcza teraz, w dobie silnego zmetaforyzowania pojęcia archiwum i tego, co zafundował tzw. zwrot archiwalny.

Za zmianę myślenia o pracy w archiwum odpowiada także to, co zaszło wraz $z$ nastaniem ery digitalizacji, gdy przekazy tekstów ${ }^{5}$ wyszły poza granice instytucji ich gromadzenia. Warto chyba zadać kilka bardzo prostych pytań, sięgając do doświadczenia, praktyki i terminologii edytorskiej. Czy to, co widzimy na ekranie, nazwać można przekazem tekstu utworu, czyli konkretnym (materialnym) jego zapisem? Czy to tylko jakaś forma jego awatara, reprezentacji rzeczywistości wirtualnej? Czy ten rodzaj styczności badacza $\mathrm{z}$ awatarem źródła wystarczy? Jeśli tak, to do czego? I kolejne pytania: czy archiwum w sensie miejsca przechowywania zbiorów jest niezbędne w pracy historyka? Czy konieczny jest fizyczny kontakt $z$ dokumentem, a przez to $z$ przeszłością? Archiwum jest przecież miejscem-instytucją takich spotkań, niedoskonałym, kontrolowanym przez archiwistę i przez tych, którzy zarządzaja jego działaniami i je nadzoruja, ale nie do zastapienia przez żadną inną formę. Taka zaś relacja, bezpośrednia, to dla wielu jedno $\mathrm{z}$ ważniejszych doświadczeń archiwum ${ }^{6}$ - możliwość fizycznego „czucia” karty papieru, jej zapachu, struktury, oceny, pod światłem, wyglądu kresów i filigranu. Nie chodzi zresztą tylko o emocje, choć i one sa ważne, ale też o możność oceny stanu zachowania przekazu, co daje pojęcie o jego użytkowaniu (lub nie), pomaga określić rozmiar kart, pozwala porównać je z kolejnymi, luźnymi albo w poszycie, sprawdzić czas wykonania zszyć - czy uczyniono to przed wpisami, czy dopiero po ukończeniu

Wersja francuska Mal d'archive. Une impression freudienne ukazała się w roku 1995, polska - pt. Goraczka archiwum. Impresja freudowska - w 2016 roku.

4 W takim kontekście przywołuje się poglądy m.in. W. Ernsta i C. Steedman. Na ten temat zob. też Markowska-Fulara, op. cit., s. 145.

5 Pojęcia przekazu używam w rozumieniu edytorskim: jako materialny zapis tekstu dzieła.

6 Zob. J. Toll e b e e k, „Turn'd to Dust and Tears”. Revisiting the Archive. „History and Theory” t. 43 (2008), nr 2, s. 237-238. 
pracy nad tekstem; daje też okazję do analizy i interpretacji ledwie widocznych wycięć kartek papieru, porównania stopnia wyczerpywania się atramentu. To wszystko ma znaczenie dla rekonstrukcji historii przekazu konkretnego tekstu, w tym jego genezy, dla rozpoznania intencji i autorskiej praktyki prowadzenia zapisków, ich cech indywidualnych i stopnia skonwencjonalizowania.

Wirtualna postać nie tylko ogranicza sposobność właściwego przebadania przekazu, gdy osoba fotografująca obiekt pominie jakiś element, np. grzbiet, okładkę czy wyklejkę zeszytu, bywa, że $z$ ważnymi informacjami, lecz zmienia percepcję oraz uruchamia inny rodzaj myślenia o przekazie i jego tekście, pozamaterialny, co ma określone konsekwencje. Ale też ktoś, kto jakiś czas spędził na wdychaniu archiwalnego kurzu i przeglądaniu dziesiątek tomów poszytów, nie da się łatwo zwieść jednopłaszczyznowości wirtualnego przekazu i wie, czego zabrakło w cyfrowym kontakcie $z$ tekstem (czy raczej z jego nośnikiem), gdy kontakt ten odbywa się za pośrednictwem ekranu właśnie.

Z ową perspektywą wiążą się już pytania dotyczące szerszego ujęcia, nie o to, co badacz robi, czego szuka w archiwum i jak interpretuje odnalezione źródła, lecz o to, co archiwum z nim czyni, jak kształtuje jego postrzeganie i ocenę materiału, oszukuje, zwodzi. I czy jest szansa się przed tym obronić - będzie jeszcze o tym mowa. Jednym $z$ podstawowych zadań historyka musi być poznanie przyjętych w archiwum (a dokładnie: przyjmowanych przez kolejnych „właścicieli”) kluczy doboru i selekcji, strategii sterowania pamięcią i jej formowania.

Archiwum jest nie tylko miejscem magazynowania, segregowania i realizacja koncepcji i praktyki przechowywania źródeł oraz opracowywania zbiorów, przetwarzania i reprodukowania przekazów „pamięci”, ale to także - zwłaszcza archiwa rodzinne, np. Archiwum Ostrowskich z Ujazdu, Archiwum Warszawskie Radziwiłłów, Archiwum Radziwiłłów z Nieborowa, Zbiór Branickich z Suchej, czy nawet „tematyczne”, jak Archiwum Masońskie, wszystkie w zasobach Archiwum Głównego Akt Dawnych w Warszawie (AGAD) - samoistna, integralna, posiadajacca własną historię, narrację całość, na którą składają się przekazy o różnorodnej tematyce, reprezentujące rozmaite gatunki i formy wypowiedzi (tekstowe, ikonograficzne, muzyczne itd.), oraz ślady materialne (pukle włosów, odznaki, guziki itp.). Słowem, nie poszczególne „rzeczy” w archiwum, lecz ogół, a więc zarówno zbiór pojedynczych dokumentów, jak i ich charakter, forma zapisu, dominacja pewnego typu źródeł, układ (czy nadany w epoce przez twórcę/twórców, czy przez archiwistę?), braki (i ich historia) - wszystko to tworzy tożsamość konkretnego archiwum.

Sporo miejsca w dyskursie dotyczącym archiwów zajmuje problem odkrycia archiwalnego i tego, co nim jest, a co nie. Czasem za takie uznaje się spektakularne wydarzenie, jak odnalezienie uznanego za zaginiony raptularza Juliusza Słowackiego z podróży na Wschód (1836-1837) ${ }^{7}$. Sięgając do odleglejszych czasów i może nieco mniej efektownego znaleziska dokonanego przez biskupa Jana Obłąka, ale dla badaczy wieku XVIII istotnego, do szczęśliwie zachowanego autografu powiastki alegorycznej Ignacego Krasickiego Prawdziwa opowieść o kamienicy

$7 \quad$ O swoim odkryciu pisze H. Głę b o cki w artykule Zaginiony raptularz Juliusza Stowackiego z podróży na Wschód (1836-1837) - odnaleziony po 70 latach w zbiorach rosyjskich („Pamiętnik Literacki” 2011, z. 2). 
narożnej $w$ Kukurowcach ${ }^{8}$, warto przypomnieć, iż analiza tego autografu każe zmienić moment datowania utworu: $\mathrm{z}$ czasu wybuchu powstania kościuszkowskiego na okres pierwszego rozbioru. Ta zaś korekta skłoniła do postawienia tezy o ingerencji cudzej ręki, i to we fragmencie uderzającym polityczną ostrością wypowiedzi, co ma wpływ także na interpretacje postaw Krasickiego wobec wydarzeń politycznych ${ }^{9}$. Bywa, że odkrycie jest kwestią trafu, albo odwrotnie - konsekwencją długotrwałych badań. W tej drugiej sytuacji punktem wyjścia staje się hipoteza o istnieniu jakichś tekstów czy zjawiska, oparta na intuicji wynikającej $z$ wieloletniej praktyki badawczej, $\mathrm{z}$ wiedzy o archiwach, $\mathrm{z}$ analizy dostępnych źródeł, którą potwierdzają dopiero kwerendy archiwalne i poszukiwania skoncentrowane na dotarciu do innych zachowanych świadectw. To przypadek prywatnych dzienników choroby z przełomu XVIII i XIX stulecia, stanowiących dotąd nierejestrowana w badaniach odmianę ${ }^{10}$, a jak się okazuje, dość powszechną w tamtym okresie i w kolejnych dziesięcioleciach XIX wieku. Jednocześnie to przykłady bardzo interesujacego świadectwa aktywnego udziału bliskich osób w chorobie jednego z członków rodziny (lub przyjaciela), w leczeniu i diariuszowym rejestrowaniu jego stanu, często agonii. Owe zapisy traktować trzeba jako efekt popularyzacji, także w prasie, wiedzy medycznej.

Wydobyte $\mathrm{z}$ archiwum przekazy historyk musi zanalizować i zinterpretować biorąc pod uwagę całe szerokie tło kulturowe, społeczne, polityczne, językowe, biograficzne, psychologiczne, w którym się pojawiły, nie pomijając aspektu materialnego. Musi ocenić ich funkcje (widoczne już w doborze formy czy gatunku wypowiedzi, ale też w przyjętych przez autora strategiach językowych, ukształtowaniu językowym czy malarskim) oraz siłę antycypacyjną materiałów (lub jej brak) stanowiących trop nowych zjawisk bądź procesów, które zachodzą w kulturze. Po jednej stronie jest więc konkretny autorski przekaz powstały w określonym kontekście, o którym była mowa, noszący cechy indywidualności twórcy, na którą składają się również strategie wykorzystywania konwencji epoki, także dotyczące form i gatunków. Po drugiej zaś - historyk wyposażony w narzędzia, warsztat filologiczny, historyczny, metody badawcze, który dokonując deszyfrowania znaczeń, celów, funkcji wpisanych w tekst i tworząc komentarze zostawia ślady, mające związek ze stosowanymi w badaniach praktykami (metodologią i środkami), ale też z prezentowanymi przez niego formacją ideowa, ukształtowaniem psychologiczno-emocjonalnym, horyzontami wyobraźni naukowej. Bywa, że owe ślady mają również charakter materialny, jak pokazują współczesne zaznaczenia czerwoną kredką na zachowanych kartach $\mathrm{z}$ obscenami czy tekstami politycznymi w archiwalnych

J. O błą k, Odnaleziony rękopis Ignacego Krasickiego. „Prawdziwa opowieść o kamienicy narożnej w Kukurowcach”. „Studia Warmińskie” t. 8 (1971).

9 Oddzielnym zagadnieniem jest szereg problemów i pytań natury edytorskiej, które to znalezisko i jemu podobne wywołują, związanych m.in. z intencją autora, podstawą wydania.

10 Można tu wspomnieć np. prowadzony przez A. O strow s ki e go Journal słabości Józi (1813), w zbiorach Muzeum w Tomaszowie Mazowieckim im. Antoniego hr. Ostrowskiego, czy Opis okropnej choroby mojej siostry Eleonory Woronieckiej prowadzony przez któregoś z braci chorej $w 1829$ ro$k u$, w zbiorach Archiwum Państwowego (AP) w Lublinie. Więcej na ten temat piszę w artykule Świadectwo dzienników choroby („Teksty Drugie” 2021, nr 1) oraz w książce, która ukaże się w Wydawnictwach Uniwersytetu Warszawskiego w serii „Communicare - Historia i Kultura”. 
zbiorach, m.in. Polskiej Akademii Umiejętności. Badacz staje się więc elementem pewnej gry ze źródłem i jego autorem, a jednocześnie elementem procesu transmisyjnego - co słusznie akcentują archiwolodzy - gry z przeszłością, z pamięcią.

\section{Digitalizacja, przyspieszenie. fragmentaryzacja}

Niemal do lat dziewięćdziesiątych XX wieku podstawową technika pozyskiwania źródeł w archiwach polskich było ręczne kopiowanie, tak działali Karol Estreicher (młodszy), Aleksander Brückner, Juliusz Kleiner czy Szymon Askenazy i setki innych badaczy przeglądających kolejne zespoły archiwów państwowych i prywatnych. Kopiowanie przekazów, jedna $z$ elementarnych operacji historyka w trakcie prowadzenia kwerend, odbywało się za pomocą ołówka (pióra) i kartki papieru. Ów sposób kopiowania $z$ równoległa lekturą - siłą rzeczy poprzedzająca moment notowania, przygotowywania wyciagów ze źródeł należących do głównego przedmiotu badań, ale także i tych będących kontekstem - oczywiście wiązać się musiał z zapamiętywaniem, identyfikacją, utrwalaniem, stanowił czynność mnemotechniczną. Dziś rękopiśmienne powielanie (i to wszystko, co się z nim łączyło) zastępują różne formy technik cyfrowych: kserowanie (też już powoli odchodzi do lamusa), fotografowanie, skanowanie. Zmianę nawyków unaocznia choćby obserwacja użytkowników Pracowni AGAD, których podzielić można na cztery podstawowe grupy: tych korzystających z mikrofilmów, tych z aparatami fotograficznymi (lub telefonami), tych od nowoczesnego skanera, wreszcie czwarta, najmniejszą, tworza pojedynczy czytelnicy tradycyjni, siedzący przy stołach nad zarezerwowanymi dokumentami.

Coraz częściej badacz funkcjonuje poza naturalną archiwoprzestrzenią, a więc miejscem przechowywania i udostępniania zbiorów. $Z$ materiałem źródłowym zaznajamia się wyłącznie w komputerze, na stronach bibliotek cyfrowych czy przeglądając wcześniej zamówione w odpowiednich instytucjach (archiwach, muzeach, bibliotekach) skany. Obraz zaś, co też nie bez znaczenia, może, przy odpowiedniej rozdzielczości, niemal do woli powiększać, nie sięgając do archaicznej lupy. Pracę $\mathrm{w}$ archiwum (instytucji) zastępuje praca w domu; uważną lekturę kolejnych pozycji w inwentarzach i przegląd archiwaliów - ekran komputera i hasłowe wyszukiwanie w cyberbazach; szeroka perspektywę widzenia, rozpoznania i rozumienia bazy źródłowej - jej fragmentaryczne i automatyczne, za pomocą wyszukiwarek, rozpoznanie; kopiowanie ręczne - pozyskiwanie skanów. Nowoczesny badacz, myślę przede wszystkim o kimś, dla kogo podstawę opisu i analizy zjawisk kulturowych, społecznych oraz politycznych stanowi materiał źródłowy, pracuje szybciej, jest znacznie „wydajniejszy”, bywa, że i efektowniejszy, ma bowiem potrzebne zbiory (lub informacje o nich), w zasadzie, w zasięgu ręki, w komputerze ${ }^{11}$.

Przyspieszenie zaczyna się zatem od procesu wynajdywania źródeł. Surfując po Internecie, także sprawdzając zasoby bibliotek i archiwów, w rozmaite wyszukiwarki coraz lepiej opracowanych baz wpisując hasła, np.: dziennik, Krasicki, Naruszewicz, Bacciarelli czy Chopin, badacz szybko uzyskuje podpowiedzi, w których archiwach może znaleźć pożądane materiały. Już na tym etapie prac dokonu-

11 Oddzielny problem wiąże się $\mathrm{z}$ możliwościami, które otwierają się dzięki edycjom genetycznym i hipertekstowi. 
je się wybiórcza selekcja, poza wiedzą badacza i - na dobrą sprawę - poza jego świadomością, intelektem, uruchamiana jednym kliknięciem w klawisz. Zmieniają się więc miejsce pracy, narzędzia, dochodzi też do redukcji czy przestrukturalizowania swoistych praktyk intelektualnych dotąd, przez wieki, towarzyszacych procedurom i działaniom badawczym związanym $z$ wyszukiwaniem, lokalizowaniem, identyfikacją. Postrzeganie obiektu badań staje się wycinkowe, a jednocześnie ulega silnemu steoretyzowaniu. Wyjęcie albo wręcz wyrwanie źródła $\mathrm{z}$ archiwalnego kontekstu, brak wiedzy, jakiego typu materiały tworzą archiwalną otulinę źródła, ograniczają szansę jego trafnej oceny. Innym problemem, nienowym przecież, jest korzystanie ze źródeł z drugiej ręki, bez ich weryfikacji materiałowej, także przy edycjach, zawsze obciążone dużym ryzykiem błędu.

Szybciej docieramy do dokumentów, zdobywamy je, kopiujemy, oszczędzamy czas. Źródło możemy powiększyć, zobaczyć pozornie dokładniej. To na pewno duża wartość. Ale proces technologicznego przyspieszenia i unowocześnienia dotyczy też warsztatu i pracy badacza, ma wpływ na postrzeganie i ocenę oraz na możliwości oceny przedmiotu studiów, na wyciaganie wniosków. Wkroczenie technik cyfrowych i Internetu to więc nie tylko nowe narzędzia pracy, to również przewrót w podejściu do samego przedmiotu badań i w obrębie sądów na jego temat.

Zmiana nośnika przekazu z papieru na ekran prowadzi do przeobrażenia lektury. Co więcej, między źródłem (w postaci cyfrowej) a badaczem pojawia się dodatkowa sieć pośredników - wskazujący materiały do digitalizacji, dokonujący tego procesu i udostepniający je w otwartej przestrzeni - którzy ingerują w sferę wyszukiwania i okazywania źródła, wkraczają w sferę kompetencji badacza. Podsumowując, powiedzieć należy, że współczesne badania tekstów kultury, w tym literatury, doby cyfryzacji i Internetu, silnie naznaczone sa ,wirusem” fragmentaryczności, selektywności, widzenia punktowego. Można prowokacyjnie zapytać: czy jeżeli przestrzeń wirtualna badacza nie wykazuje jakichś zjawisk, procesów, autorów ani tekstów, albo ich frekwencja w zasobach online jest bardzo nikła, czy to oznacza, że np. owe zjawiska i procesy nie miały w kulturze miejsca? Dobrze ilustrują złożoność sytuacji wspomniane wcześniej prywatne dzienniki choroby z XVIII i XIX stulecia. Jak interpretować fakt, że w czasie dużego zainteresowania dokumentami osobistymi, w tym diariuszami, literatura przedmiotu na temat dzienników choroby milczy? Dlaczego polska diarystyka intymna z poczatku wieku XIX tak długo umykała oku historyków, a za jej datę startową uznawano dopiero drugą połowę stulecia XIX ze wskazaniem na przełom XIX i XX wieku? Bazy cyfrowe, ujawniające tylko przetworzony fragment zachowanych źródeł, nie udziela odpowiedzi na te pytania, nie zastapią wiedzy o powojennych, ideologicznych strategiach gromadzenia zbiorów i budowania poszczególnych zespołów archiwalnych, o wpływie doktryny politycznej na charakter kolekcjonowanych materiałów; o kontekście historycznym, kulturowym czy biograficznym już nie wspominając. Historyk kultury nastawiony na szeroko rozumianą prace źródłową powinien dążyć do uzyskania, przynajmniej w założeniu, wiedzy totalnej o źródle - w sensie horyzontów wyobraźni archiwalno-kulturowej - wymykającej się fragmentaryzacji, czułej na wszelkie sygnały, które sugeruja istnienie nowych, dotąd nieodkrytych zjawisk, albo przesunięcie granic chronologicznych tych, jak się wydawać by mogło, dobrze rozpoznawanych. W tym wypadku ważne jest nałożenie się wielu kompetencji - 
liczą się zarówno wiedza na temat badanego okresu oraz zachodzących wówczas wydarzeń i procesów, jak i właściwy, czyli nieprzypadkowy, niejednorazowy, kontakt i obeznanie $z$ archiwalnymi zasobami - co pozwoli powiąać znajomość zjawisk epoki $z$ dostępnymi źródłami, a także na podstawie odnalezionych nowych materiałów zmodyfikować pojęcie o epoce. Wreszcie, co najtrudniejsze, tylko pod takimi warunkami da się też projektować istnienie (hipotetyczne) zjawisk, o których nic nie wiadomo, a które dyktuje wiedza o tym, co potwierdzone. To przypadek szerszego fenomenu, którym jest funkcjonowanie w dziejach, wspomnianych już tu, prywatnych dzienników choroby czy prywatnych szkicowników malarskich, takich jak Józefa Łeskkiego, profesora matematyki, fizyki i astronomii w Liceum Warszawskim i w krakowskiej Szkole Głównej, dyrektora tamtejszego obserwatorium astronomicznego; dobry przykład karier absolwentów Szkoły Rycerskiej. Łęski to także artysta amator, autor licznych akwafort i miniatur, historycznych i alegorycznych kompozycji, z których największą popularność przyniósł mu miedziorytowy portret Tadeusza Kościuszki, przedstawiający naczelnika powstania z wzniesioną oburącz szablą, podstawa szeregu prac dotyczacych generała, sztychów, a nawet pierścieni ${ }^{12}$. Zachowały się dwa szkicowniki Łęskiego - pierwszy prowadzony w czasie niewoli, 1794-1795; w drugim, z lat 1809-1819 ${ }^{13}$, znajdujemy rysunki i akwarele Łęskiego oraz kopie prac przede wszystkim podziwianych przez niego artystów: Rafaela, a także szereg, jak to nazwał Władysław Tatarkiewicz, „przerobień” obrazów Tycjana, Carla Marattiego, Giambattisty Piranesiego, Jacques'a-Louisa Davida, ale też „przerobienia” czy odrysy prac Marcella Bacciarellego (m.in. Portretu Katarzyny Gattai Thomatis), liczne Franciszka Smuglewicza. Obok rysunków pojawiają się teksty towarzyszace, np. akwarela Abassa spoczywajaca na sofie po kapieli (18091811?) uzupełniona fragmentem wiersza Franciszka Karpińskiego Wezyr Gijafar do Haruna al-Raszid, kopia Trzech etapów życia ludzkiego Tycjana uzupełniona wierszem Krasickiego Nędze ludzkiego stanu, oraz, osobno, utwory poetyckie Adama Naruszewicza, Józefa Lipińskiego, Ignacego Potockiego i innych.

\section{Patrzenie drukiem}

Z badaniami dotyczącymi XVIII i pierwszej połowy XIX wieku jest jeszcze jeden kłopot, który najkrócej nazwać by można problemem dominacji druku w świadomości badawczej. To druk właśnie, w jakimś sensie, porządkuje myślenie wielu historyków, także historyków języka, o zjawiskach kultury XVIII, ale też i XIX stulecia, staje się punktem odniesienia w postrzeganiu piśmiennictwa epoki, hierarchii tematów, autorów, problemów bądź gatunków - niezależnie, czy chodzi o literatu-

J. Łę ski, Tadeusz Kościuszko, z szabla wzniesiona oburacz, $w$ mundurze generalskim, prawy profil. Muzeum Narodowe w Warszawie, Gr.Pol.25068. - [Twórca nieznany], Pierścień z podobizna Kościuszki. Jw. SZM 1112. Na stronie: https://cyfrowe.mnw.art.pl/pl/katalog/435802 (data dostępu: 25 IV 2021).

13 J. Łę s ki: szkicownik z lat 1794-1795. Jw. Rys.Pol.5979/1-70; szkicownik z lat 1809-1819. Jw. Rys.Pol.1760/1-105. Drugi szkicownik dobrze opisał W. Tatarkiewicz w studium Rysunki Łęskiego (.,zztuka. Miesięcznik ilustrowany, poświęcony architekturze, grafice, literaturze, malarstwu, muzyce, rzeźbie, sztuce stosowanej, teatrowi oraz zagadnieniom twórczości i sprawom sztuki" 1914, z. 20/22). 
rę wysoką, rozwój różnych form twórczości, historię języka, czy np. o literaturę dokumentu osobistego. Oczywiście, powstają nowe edycje źródeł, wybory lub dzieła zebrane, przy których opracowaniu sięga się do źródeł rękopiśmiennych, to jednak działania punktowe, skupione na twórczości konkretnej postaci czy na wybranym korpusie tekstów. Ale materiału do analiz interdyscyplinarnych, z pogranicza literatury i sztuki wizualnej, do studiów nad pamięcią, cielesnością (to zresztą temat właściwie nie podjęty przez polskich uczonych zajmujących się oświeceniem i początkiem XIX wieku), do badań dzienników intymnych z początku stulecia XIX, zwłaszcza prywatnych dzienników choroby bądź prywatnych szkicowników malarskich, ani nie znajdzie się wśród tekstów drukowanych, ani nie pomoże tu użycie odpowiedniej internetowej wyszukiwarki. Kilka różnych przykładów, o jednym zresztą była już mowa, myślę o Krasickiego Prawdziwej opowieści i o korektach, które trzeba było wprowadzić w datowaniu tekstu po odkryciu jego autografu. Podobna historia wiąże się z Dumaniami żotnierza polskiego $w$ starożytnym zamku Mazurów nad Tagiem Kantorberego Tymowskiego i dotyczy różnic zachodzących między redakcją rękopiśmienną a tą, która ukazała się drukiem w 1815 roku. Jedynie ta pierwsza pochodzi $z$ epoki, $z$ okresu wojen napoleońskich w Hiszpanii, znacznie zresztą krótsza, tylko w niej występuje imię Napoleona i jej lektura każe odrzucić dość często pojawiającą się nadal w badaniach historycznych refleksję o wpisanych w treść Dumań krytyce i zniesmaczeniu walką Polaków w Hiszpanii. Sensy te znalazły się w strofach Tymowskiego, ale dopiero w druku, w 1815 roku, po upadku Napoleona ${ }^{14}$. Innym przykładem jest historia redakcji drukowanej i rękopiśmiennej Dyjaryjusza podróży jego Królewskiej Mości na Sejm Grodzieński Naruszewicza i odmian tekstu ${ }^{15}$. Oddzielne zagadnienie stanowią znacznie szersze zjawiska literackie czy paraliterackie, których znajomość opiera się przede wszystkim na tekstach drukowanych. To problem poezji wolnomularskiej, której tylko mały procent ujrzał do tej pory światło druku: najczęściej autorów uznanych, ba, często nie masonów, choć ich utwory dostosowane zostały do potrzeb antologii wolnomularskich publikowanych w epoce. Dopiero sięgnięcie do nierozpoznanej dotąd twórczości zachowanej w rękopisach pokaże skale zjawiska, zarówno jego wymiar ilościowy, jak jakościowy, obowiązujące tematy, motywy, a także zróżnicowanie gatunkowe i specyfikę językową. Jeszcze poważniejszym kłopotem jest wciąż bardzo nikła wiedza na temat zachowanej w rękopisach literatury dokumentu osobistego wieku XVIII i początków XIX, przede wszystkim rozmaitych odmian zapisów pamiętnikarskich, diariuszy, również prywatnych szkicowników malarskich prowadzonych nie dla ćwiczenia ręki i oka, lecz po to, by, często paralelnie do dzienników, rejestrować otaczająca autora najbliższą rzeczywistość. O powszechności tego typu notowań w epoce nikogo nie trzeba przekonywać, ale o jej stopniu wiadomo niewiele, o równoległym prowadzeniu diariuszy, podobnie zreszta jak i prywatnych szkicowników malarskich, przez członków tej samej rodziny: mężów, żony, dzieci, siostry czy braci, co pokazują archiwa np. Radziwiłłów lub Czartory-

14 Na ten temat zob. publikacje mojego autorstwa Kantorbery Tymowski $w$ świetle nowych źródeł (Warszawa 2002).

15 A. N a r u s z e w i c z, Dyjaryjusz podróży jego Królewskiej Mości na Sejm Grodzieński. Wyd. M. B ob e r - J a n k ow s ka. Warszawa 2008 (zob. zwłaszcza aparat krytyczny). 
skich. Te i inne materiały rozsiane po archiwach podworskich dostarczają dużo ważnych informacji na temat samej praktyki prowadzenia tego rodzaju dokumentów życia osobistego (na pojedynczych kartach, na kartach kalendarzy potem łączonych w tomy, w specjalnych poszytach), poza tym to też wartościowe źródła wiedzy o życiu kulturalnym (np. o teatrach societé - działalność wielu z nich trzeba na podstawie owych zapisków inaczej datować) czy politycznym. Tylko weryfikacja poprzez zbiory rękopiśmienne, i to analizowane $z$ natury, pokazać może zróżnicowanie w typach diariuszy, także tych tworzonych przez sekretarzy, udział kobiet. Pierwsza duża korekta myślenia o rozwoju diarystyki na ziemiach polskich już się dokonała po odkryciu dzienników Antoniego Ostrowskiego z 1813 roku, Życia najlepszej żony... oraz Dziennika uczuciów, czyli elegii serca, które udowodniło, że często powtarzanej tezy o spóźnionym, o 100 lat w stosunku do Europy Zachodniej, pojawieniu się na terenach polskich dziennika intymnego, nie da się utrzymać. Zjawisko to lokować trzeba najpóźniej właśnie na przełomie wieków XVIII i XIX, przemawia za tym też twórczość diarystyczna Atanazego Raczyńskiego z tego okresu $^{16}$.

\section{Archiwum - archiwalia - badacz}

O ile we współczesnej refleksji sporo miejsca poświęca się archiwum, jako zjawisku społecznemu, politycznemu, i dokumentom - ich poznawczemu statusowi, różnym aspektom tworzenia, ich pozycji świadka w procesach rekonstrukcji wydarzeń oraz ich wiarygodności, o tyle znacznie mniejsze zainteresowanie budzi materialność dokumentów, tak wyraźnie akcentowana w studiach edytorskich (na czym, czym i w jaki sposób?), a także to, co w edytorstwie wiąże się $z$ odtworzeniem tradycji szeroko rozumianego tekstu (tekstu utworu literackiego, dokumentu osobistego, dokumentu historycznego itd.): data powstania, atrybucja, liczba (czy historia) zachowanych autografów oraz sporządzonych odpisów, druków i, co najważniejsze, relacje między nimi. Charakter wprowadzanych zmian w rękopisach: zamazany zapis, nadpisanie, zszycie kart (na fragmentach wpisów, lub nie), jak też liczba przekazów tekstu, kopii - to świadectwa nie tylko istotne dla poznania dziejów konkretnego źródła, ale również mające duże znaczenie dla tożsamości i historii jednostki, zespołu i, ostatecznie, archiwum; podobnie jak rodzaj papieru, atrament, dukt pisma, typ czcionki czy wycięta karta (ślad po wycięciu: karta wyrwana, wycięta nożykiem).

Większy udział refleksji edytorskiej, wypracowanych przez nią metodologii i narzędzi, perspektywy patrzenia na źródła (problem odpisów, druków, odmian tekstów), pozwoliłyby uzyskać, jak się wydaje, funkcjonalne instrumentarium do studiów nad pamięcią - także w świetle badań nad XVIII i początkiem XIX wieku. Zresztą również ustalenia zwrotu archiwalnego mogą otworzyć nowe perspektywy postrzegania przekazu, jego funkcji, procesu tworzenia czy odtworzenia. Za wzór niech tu posłuży kariera terminu „świadek”, jednego z ważniejszych zarówno w badaniach nad pamięcią, jak i nad archiwaliami. Pojęcie świadka i procedury wiążą-

16 A. Raczyński, Dziennik. T. 1: Wspomnienia z dzieciństwa. Dziennik 1808-1830. Przekł., oprac. A. W. Labuda, M. Mencfel. Poznań 2018. 
ce się z jego wyłanianiem też należą do najistotniejszych elementów myśli edytorskiej, tj. krytyki tekstu. Badacz przygotowujący wydanie krytyczne utworu pragnie, myślę o klasycznym edytorstwie, dotrzeć do najbardziej wiarygodnego, poprawnego przekazu, najbliższego autorowi (i jego intencji) ${ }^{17}$, do świadka, który stanie się podstawą publikacji, a więc dalszej reprodukcji pamięci. Stosowane sposoby postępowania prowadzace do edycji krytycznej można uznać za dobry przykład odzyskiwania śladów przeszłości, ale i, równolegle, zostawiania własnych. Reguły tekstologiczne wykorzystywane przy opracowywaniu tekstu autorskiego, wśród których nadrzędną pozycję zajmuje intencja autora, ukierunkowane są właśnie na tropienie zostawianych śladów (także świadomych odmian czy błędów kopistów, drukarzy-wydawców) i wskazanie świadka, który będzie podstawą edycji też naznaczonej śladami pamięci, wiedzy, kompetencji edytora i badacza, co otwiera kolejne przestrzenie interpretacyjne, również nad prawdą i pamięcią przekazu oraz strategiami jej modyfikacji.

Interesujacym źródłem do badań na tym polu jest ikonografia, m.in. dziesiątki rysunków, akwarel i litografii z podobizna Chopina, realizujących motyw l'homme sur son lit de mort, czy z postacia Kościuszki. Jak wyglądały strategie przekazywania, przenoszenia ich wizerunków chociażby z rysunku na miedzioryt czy litografię, po fotografię? Jakie modyfikacje dokonywały się przy tych transferach i jaką funkcje pełniły? Każda reprodukcja pociąga za sobą różnice w treści przekazu, także wtedy, gdy dotyczy tego samego nośnika, np. kartki papieru i ołówka. Nawet zmiana typu papieru, ołówka, przede wszystkim ręki i oka (ten sam autor lub nie, dyspozycja psychiczna i fizyczna twórcy w danym momencie), nie mówiąc o uzupełnieniach tekstowych, prowadzić będą do przeobrażeń, czasem drobnych, w zawartości przekazu. Wybór medium, np. litografii czy fotografii zamiast rysunku, skutkuje odmiennościami natury semantycznej w ramach przekazu, ma też zasadniczy wpływ na jego odbiór.

\section{Artefakty przeszłości i ich materialność}

Określony kształt fizyczny nadany dziennikom, szkicownikom, innym zapisom, także ikonograficznym, przez twórców lub ich otoczenie stanowi jeden $z$ wyznaczników tych form. Np. kilku luźnych, rozproszonych kart nikomu nie przyjdzie do głowy nazywać szkicownikiem. Ten musi mieć konkretną ramę scalająca, właśnie materialną. Dziennik wymaga znów ciagłej, codziennej niemal praktyki, w innym wypadku przestaje być dziennikiem. Zdarza się, że i on otrzymuje odpowiednią ramę scalająca, a taki gest autora lub jego potomków należy odnotować i zinterpretować. Dziennik bywa bowiem prowadzony na luźnych kartach, potem zszytych, lub od razu w poszycie; niekiedy notatki dodatkowo uzyskuja jeszcze ozdobna oprawę. Ważne jest więc to, na czym (lub w czym) dokonywano zapisów, ale także w jaki sposób, zarówno jeśli chodzi o dukt pisma (czy typ zapisu graficznego w szkicowniku: szkic, rysunek), strategie wykorzystywania (zapełniania) stron kart (wy-

17 Temu problemowi poświęcili wiele miejsca w swoich pracach dotyczących edytorstwa np. K. Górski, R. Loth czy Z. Goliński. Nieco inaczej wygląda sytuacja „intencji autora” po tzw. zwrocie genetycznym. 
pełniania pustych przestrzeni, zostawiania pustych kart itd.), paginowania (numerowania stronic) albo foliowania (numerowania kart), jak i o narzędzie i tryb jego użycia (czy jednorazowo, słowem, czy zmienia się odcień atramentu, w przypadku zaś szkicownika to pytanie o technikę przedstawienia). Znaczenie ma też, gdzie zapisy przechowywano, czy funkcjonowały w tradycji rodzinnej i czy były komentowane poprzez dodanie uzupełnień (tekstów, podkreśleń, rysunków). To wszystko jest istotne dla zrozumienia fenomenu osobistych dzienników i prywatnych szkicowników, roli i funkcji pełnionych w życiu ich autorów oraz dla refleksji nad zasadnicza przemianą dokonująca się na przełomie XVIII i XIX wieku, odczuwalną po dziś dzień, której obie te formy stanowią zarazem konsekwencję i ważne świadectwo, a którą najogólniej nazwać by można wielkim zwrotem ku prywatności.

\title{
Paradoks archiwalny
}

Historyka literatury interesują materiały, które z upływem czasu nabierają, zazwyczaj, wartości. Są coraz starsze, coraz bardziej służą rozpoznaniu dawnych epok. $Z$ kolei archiwista stoi na straży owych artefaktów. Badacz sięgając po autentyczny dokument, list, wiersz, staje się kimś, kto archiwiście zagraża. Każde udostępnienie naraża dokument na niebezpieczeństwo. Nawet przy zachowaniu największej ostrożności kontakt naukowca z materiałem może go, choćby w niewielkim stopniu, zepsuć. Fototypiczne wydanie Pana Tadeusza ma dla specjalisty od twórczości Mickiewicza wartość ograniczoną. Dotarcie do oryginału wiąże się z koniecznością pokonania wielu barier. Szlachetny opór archiwisty kłóci się z potrzebą badawczą. Bez pracy z autentycznym dokumentem, listem, poematem, ale także rysunkiem, dagerotypem, fotografią, tracimy ogromną część naukowej refleksji historycznej i historycznoliterackiej.

\author{
Abstract \\ ELŻBIETA WICHROWSKA University of Warsaw \\ ORCID: 0000-0001-7151-6213
}

\section{THE RESEARCHER IN ARCHIVE AND THE RESEARCHER'S ARCHIVE AN ARCHIVE} PARADOX

In recent years, the term "archive" in academic discussions has drifted away from its basic meaning (a place of acquiring, segregating, selecting, and cataloguing collections in a given socio-political and cultural space) to adopt the function of a conceptually attractive metaphor-a figure of political discourse, an institution of power, or memory. The changes (archive turn) are followed by some other ones caused by invasion of virtual world into the archive space (digitalisation) between the researcher and the source. Such transformations not only impose redefining the notions such as text transmission which are fundamental for the critical and historical research, but also call for the role of their materiality (material versus virtual transmission). In addition to that, it is argued whether digital repositories can replace the traditionally understood archives, which impact and effect they may have on the researcher when it comes to the replacement of the classical contact with the source with the digital medium (acceleration of the work, fragmentarisation), how they change the way of thinking about the research subject, how they influence the extensive analysis of the research material and, in consequence, broader phenomena and cultural process, including literary ones. The extent to which a researcher relies on printed transmissions affects the perception of literary phenomena and formation of canons is a separate issue in the paper. 